\title{
Performance Study of Tractor Operated Rotary Plough in Two Different Soils
}

\author{
B. Jithender ${ }^{1 *}$, D.V. Sunitha ${ }^{2}$, K. Upender ${ }^{3}$ and K.V.S. Rami Reddy ${ }^{4}$ \\ ${ }^{1}$ Department of Agricultural Processing and Structure, CIAE, Bhopal, M.P., India \\ ${ }^{2}$ Department of Soil and Water Engineering, CAE, Bapatla, A.P., India \\ ${ }^{3}$ Department of Farm Power and Equipment, CIAE, Bhopal, M.P., India \\ ${ }^{4}$ Department of Farm Machinery and Power, CAE, Bapatla, A.P., India \\ *Corresponding author
}

\section{A B S T R A C T}

\begin{tabular}{|l|}
\hline Ke y w or d s \\
Theoretical field \\
capacity, Actual \\
field capacity, Field \\
efficiency.
\end{tabular}

In India, area under cultivation is about 159.7 million ha. $68 \%$ of the total net sown area comes under dry land cultivation, spread over 177 districts. As farmers turn increasingly to multiple cropping systems to boost their incomes and meet increased demand for their produce, the time available for seedbed preparation has decreased considerably. This can be met by using rotary plough. The rotary plough was evaluated at Ramkur village and College of Agricultural Engineering, Bapatla for its field capacity, field efficiency and fuel consumption in two different soils i.e., black soil and sandy soil. Parameters such as width of cut, depth of cut, field capacity, field efficiency and fuel consumption before and after ploughing were determined. The result of the field experiments showed that the effective field capacity of the implement in black and sandy soil as $0.18 \mathrm{ha} / \mathrm{h}$ and $0.28 \mathrm{ha} / \mathrm{h}$ and the theoretical field capacity of black and sandy soil as $0.30 \mathrm{ha} / \mathrm{h}$ and $0.375 \mathrm{ha} / \mathrm{h}$ respectively. Hence it may be concluded that this implement gives a field efficiency of $60.20 \%$ and $74.68 \%$ in black and sandy soil respectively.

\section{Introduction}

In India, area under cultivation is about 159.7 million ha. $68 \%$ of the total net sown area comes under dryland cultivation, spread over 177 districts. The increase of any crop production in both quantity and quality depends mainly on the improvement of soil and plant condition. This can be achieved by suitable tillage tool. However the selection of tillage implements for seedbed preparation and weed control depends on soil type condition, type of crop, previous soil treatments, crop residues and weed type (Upadhyaya et al., 2009). Tillage is a process of creating soil condition for seed germination and growth of crop (Al-suhaibani and Ghaly, 2010). It is considered one of the biggest farm operations as tillage operation requires the most energy on the farm. Tillage is of two types: primary tillage and secondary tillage. Primary tillage operation consists of the initial major soil working operation, it is normally designed to reduce soil strength, cover plant materials and rearrange aggregates. For primary tillage operations, implements like mould board plough, disc plough, chisel plough, subsoiler, rotary plough are used. Secondary tillage operations are intended to create refined soil condition following 
primary tillage. For secondary tillage operations implements like offset disc harrow, cultivator, blade harrow are used.

Rotary plough is a primary tillage implement. It is a Europe origin plough. The rotary plough may be divided into three types- pull auxiliary engine, pull power take off driven, and self-propelled Garden type. This consists of set of knives or tines rotated on a shaft by a power source. The knives chop the soil up and throw it against a hood that covers the knive set. These are rotational tillage implements that break and mix the soil by using either the tractors power (rotary tiller rotary power harrow) or an external source (small motorized rotary tiller) and the operation typically needs only one pass to let the soil ready for planting.

Tillage implements may be animal drawn or tractor drawn. The choice of mechanical, animal or manual power for any work in the farm revolves round on the relative cost of different forms of power for doing unit of work for particular type under consideration (Sankaran and Mudaliar, 1984). Now-a-days most of the Indian farmers are using tractor drawn improved agricultural implements and machines for different operations in field. Preparation of seedbed includes operations such as ploughing, disking, cultivating, harrowing etc. These operations give betterpulverized soil leading to friable and properly aerated soil ideal for better germination seed.

As farmers turn increasingly to multiple cropping systems to boost their incomes and meet increased demand for their produce, the time available foe seedbed preparation has decreased considerably. Some of the most common problems caused by inadequate tillage operations include the increase in soil bulk density, compaction, reduced infiltration, hydraulic conductivity among others that effect the plant growth.
One such implement is available at FMP department, CAE Bapatla. This implement could cover 4 acre/day in case of black soils and 6 acre/day in case of sandy soils. This can till the soil to a depth of about 6.5 inches in black soils and about 7.5 inches in sandy soils. Using the rotary plough field can be prepared within a time period of 15 days. This implement can be used for dry and firm soils. These can be considered critical under tropical climate condition due to their strong impact on soil structure and the high erosion risk involved (Glab and Kulig, 2008; Gonzalez et al., 2007). The cost of rotary plough ranges from 100000 to 300000 per unit.

\section{Advantages of rotary plough}

(i) Its long and sharp blades can easily plough any land and it is most suitable for converting barren land into cultivable. (ii) These create good seedbeds. (iii) Wide range of working width available starting from $100 \mathrm{cms}$ to $250 \mathrm{cms}$ to suit 45 and above HP tractors. (iv) Its Sturdy structure is welded with high thickness plates which make sure that it operates under toughest conditions. (v) Its gearbox designed with quality components promises longer life cycle of the implement. (vi) It ensures faster operation and completes function in less time and minimum diesel consumption than any other tractor operated primary tillage implement. (vii) The purpose of testing and evaluation of tillage implements under the laboratory and actual field conditions is to recognize their quality and output. (viii) This will help the in controlling the undeserving units, improving the deficiencies in existing implements, saving the energy through the adoption of energy efficient implements based on need of rotary plough. Testing and performance evaluation of rotary plough which is available at FMP department, CAE Bapatla was taken with the objective of studying the working 
performance of the plough in two different types of soils.

Hugo Gonzalez et al., (2013) studied the wear resistance of rotary plows operating in a clay loam soil. The degree of damage caused to the soil and the amount of mass lost by the tools were determined. Field tests were carried out in 12 plots and a randomized experimental design with 4 tillage implements: rotary tiller, rotary power harrow, small motorized rotary tiller and control (unaltered soil), 3 replicas per implement and 2 passes per plot were applied. The highest mass losses were measured in rotary tiller and rotary power harrow tools. This is affected by effective contact time between tool and soil, the rotating speed and the sudden impact forces. Khadr (2000) reported that power and energy requirements for tilling the soil increased by increasing the tilling depth. The rotary plow gives the lowest fuel consumption and energy requirements compared with the chisel plow (one pass), chisel plow (two passes) and moldboard plow followed by disc harrow, where the energy requirements were (12.28, $13.35,23.8$ and $37.87 \mathrm{~kW}$. h. fed ${ }^{-1}$ ) for rotary plow, chisel plow (one pass), chisel plow (two pass) and mouldboard plow followed by disk harrow, respectively. Abdou (1996) stated that using of rotary plow or disc harrow after chisel plow for preparing the seed-bed at clay-loam soil gives a higher yield of grain and straw compared with chisel plow two passes for wheat crop. On other hand, using the rotary plow at $10 \mathrm{~cm}$ depth increased the yield of barley (grain and straw) by $4.74 \%$ and $8.86 \%$, respectively.

\section{Materials and Methods}

The field experiment was conducted to study the performance evaluation of rotary plough. The experiments were conducted at Ramkur village (black soil) and college of agricultural engineering, Bapatla (sandy soil). The details of materials used, experimental methodology and experimental techniques adopted during experiments were described in this chapter. Rotary plough implement was evaluated for its effective field capacity, theoretical field capacity, field efficiency and fuel consumption in two different fields of size $(54 \mathrm{~m} \times 35 \mathrm{~m})$ and $(49 \mathrm{~m} \times 21 \mathrm{~m})$.

\section{Shaktiman rotary plough [SRP 4/1000 (10 Blade)]}

\section{Description}

Shaktiman rotary plough is a primary tillage implement. Its blades are sharp and long enough to till depths of any soil and improve its organic structure. Its body frame work is strongly built and promises longer durability which makes it a reliable implement. Shaktiman rotary plough is considered the toughest in its category. It can till great depths, break massive clumps and ensure even leveling in just one pass. It is also very useful for converting a barren land into cultivable. Compared to any other tractor operated primary tillage implement, it saves more time and money. Wide range of working widths are available starting from $100 \mathrm{~cm}$ to $250 \mathrm{~cm}$ to suit 45 and above HP tractors.

\section{Performance evaluation of implement}

\section{Width of cut}

For determining width of cut, average of 5 runs was taken. The measurement of composite width was taken at 5 equidistant places in the direction of travel and average working width was determined.

\section{Depth of cut}

The vertical distance between furrow sole and ground level is referred as depth of cut. To obtain accurate result, the depth was 
measured at 10 places and its average was taken.

\section{Effective field capacity}

The actual output in terms of area covered per hour is expressed as the effective field capacity. In calculating the effective field capacity, the time consumed for the real work and that lost for other activities such as turning, adjustments etc. was taken. Time for refueling was deleted because usually filling up before starting the test made refueling unnecessary as the field size is small. It was calculated as:

$E_{e}=\frac{A}{T_{P}+T_{N}}$

Where,

$\mathrm{E}_{\mathrm{e}}=$ effective field capacity $(\mathrm{ha} / \mathrm{h})$

$\mathrm{A}=$ area covered (ha)

$\mathrm{T}_{\mathrm{P}}=$ productive time $(\mathrm{h})$

$\mathrm{T}_{\mathrm{N}}=$ Nonproductive time $(\mathrm{h})$

\section{Field efficiency}

The field efficiency is the ratio of effective field capacity to the theoretical field capacity expressed as percentage.

Theoretical field capacity (ha/hr) = Theoritical width of the implement $(\mathrm{m}) \mathrm{X} \operatorname{speed}\left(\frac{\mathrm{m}}{\mathrm{hr}}\right)$

10000

Field efficiency $(\eta)=\frac{\text { Effective field capacity }}{\text { Theoritical field capacity }}$

For most of the tillage operations field efficiency range between $75-90 \%$.

\section{Fuel consumption}

The tank was filled to full capacity before and after the test. Amount of refueling after the test was the fuel consumed for the test. The tank was filled without any empty space. The fuel consumption gives an idea of energy requirement by the implement for the operation.

\section{Results and Discussion}

The field experiment was conducted to study performance evaluation of rotary plough. The experiments were conducted at Ramkur village and college of agricultural engineering, Bapatla. The results obtained during the performance evaluation of implement, such as theoretical field capacity, effective field capacity, and field efficiency are presented in this chapter.

\section{Type of soil}

Black and sandy soil

\section{Field performance}

The speed of the implement in black and sandy soil was $2.5 \mathrm{~km} / \mathrm{h}$ and $3 \mathrm{~km} / \mathrm{h}$ respectively and the width of cut of the implement was $1 \mathrm{~m}, 1.20 \mathrm{~m}$ in black and sandy soil respectively and shown in table 1 .

\section{Field efficiency}

The effective and theoretical field capacity of rotary plough was calculated in two different fields. It was found that the effective field capacity of the implement in black and sandy soil as $0.18 \mathrm{ha} / \mathrm{h}$ and $0.28 \mathrm{ha} / \mathrm{h}$ and the theoretical field capacity of black and sandy soil as $0.30 \mathrm{ha} / \mathrm{h}$ and $0.375 \mathrm{ha} / \mathrm{h}$ respectively.

Hence it may be concluded that this implement gives a field efficiency of $60.20 \%$ and $74.68 \%$ in black and sandy soil respectively. From the graph above, it can be concluded that field efficiency by using the rotary plough is more in sandy soil compared to black soil. 
Plate.1 Rotary plough

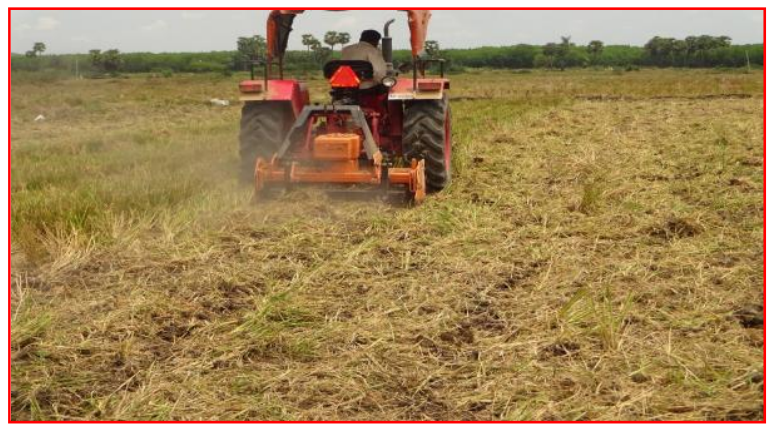

Plate.2 Measurement of width of cut in black soil and sandy soil
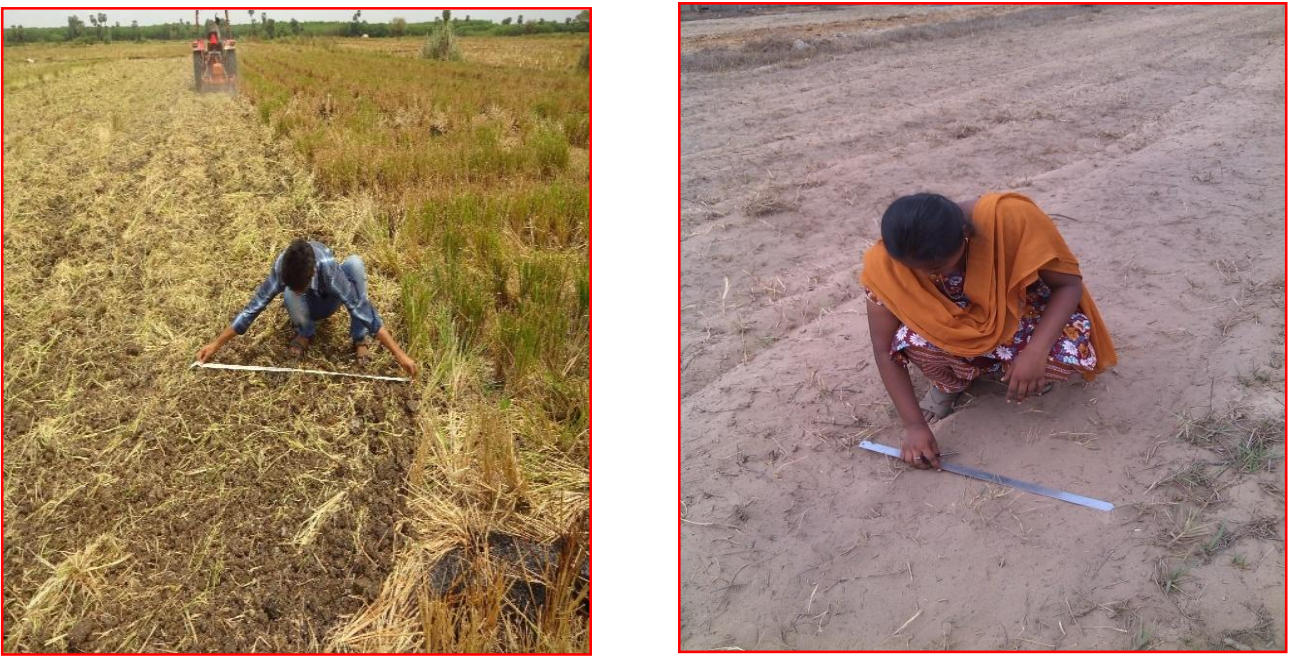

Plate.3 Measurement of depth of cut in black soil and sandy soil
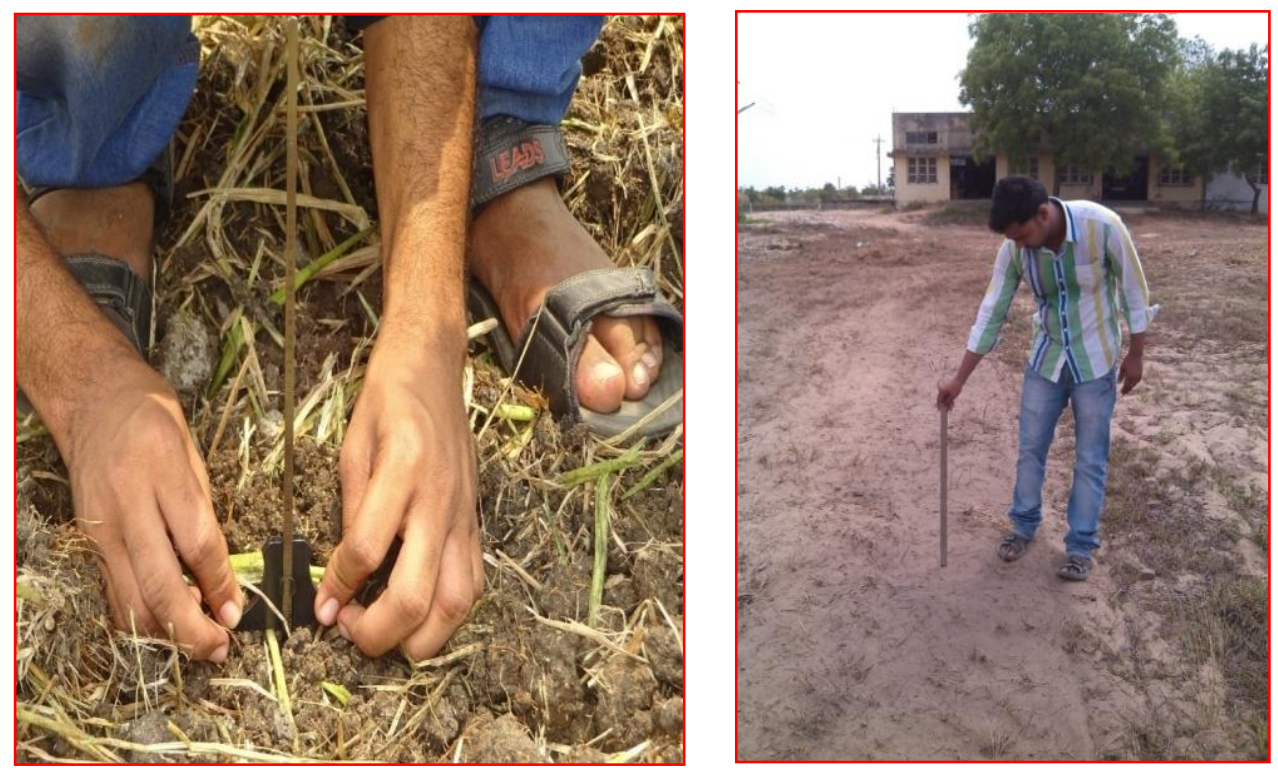
Plate.4 Land before and after ploughing at Ramkur village (black soil)
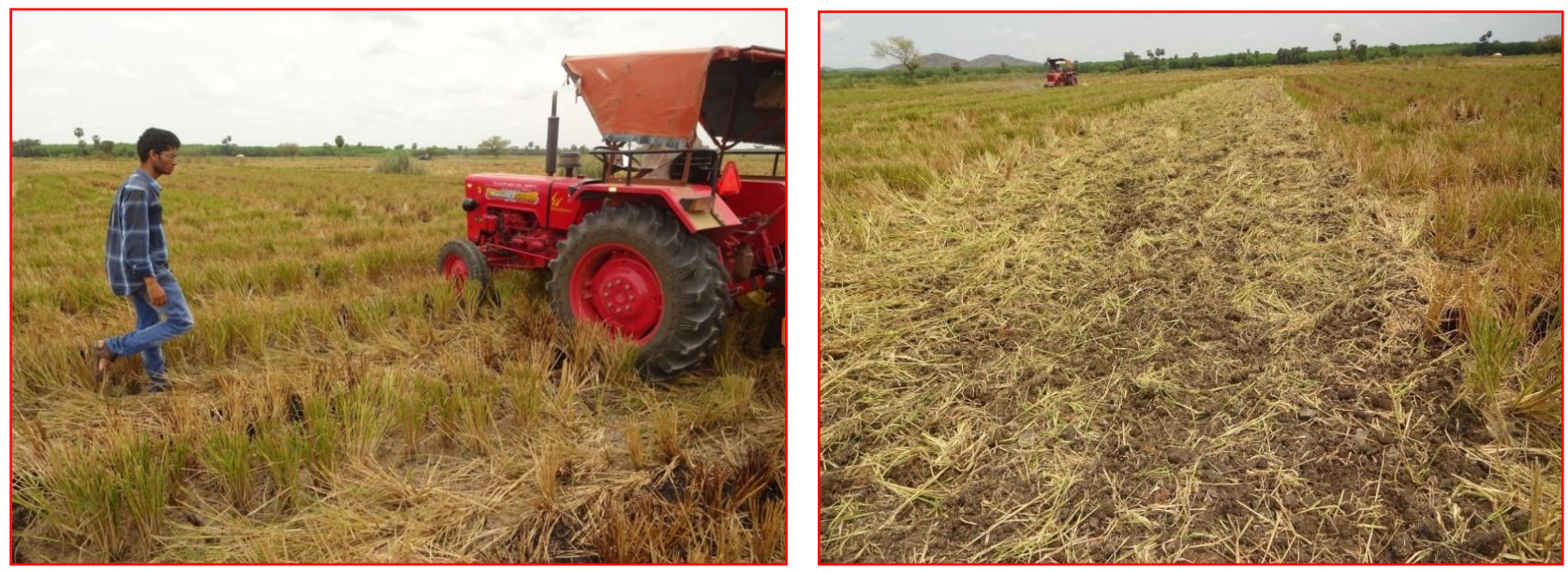

Plate.5 Land before and after ploughing at College of Agricultural Engineering, Bapatla
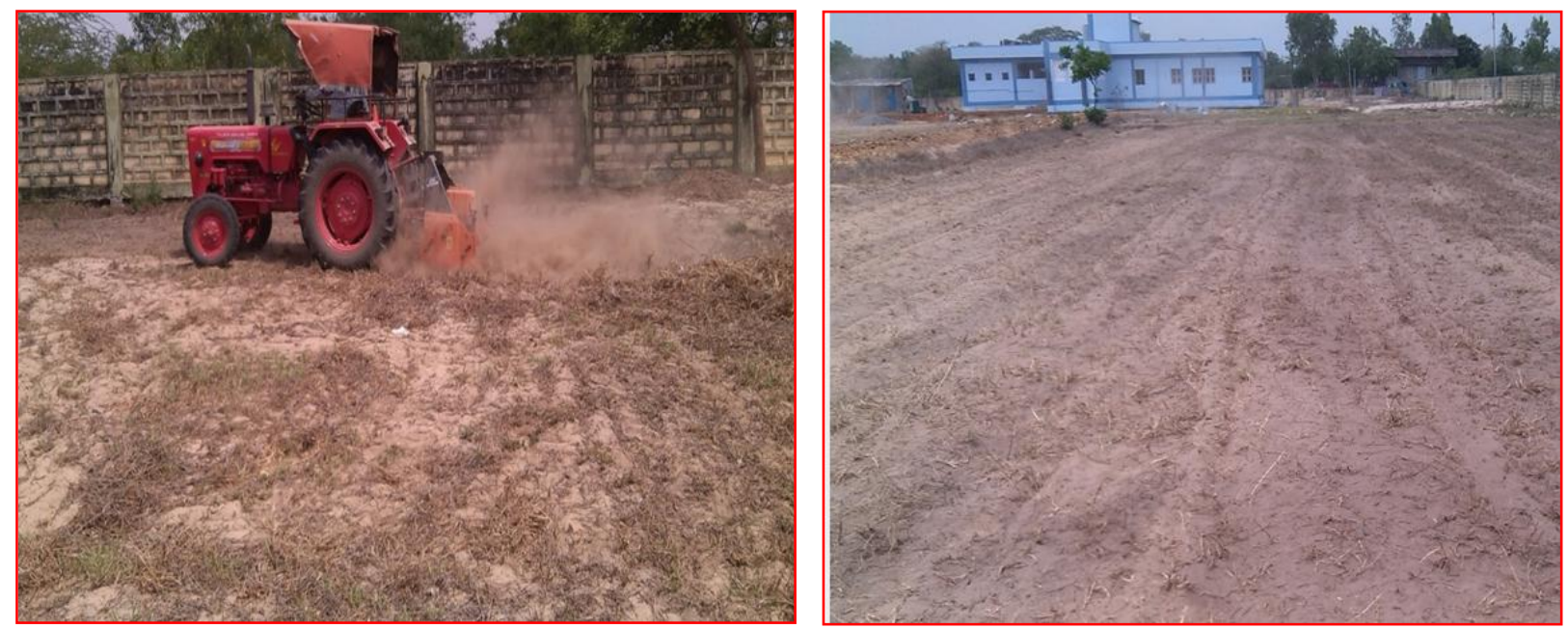

Fig.1 Graph showing comparative field efficiency of implement in two different soils

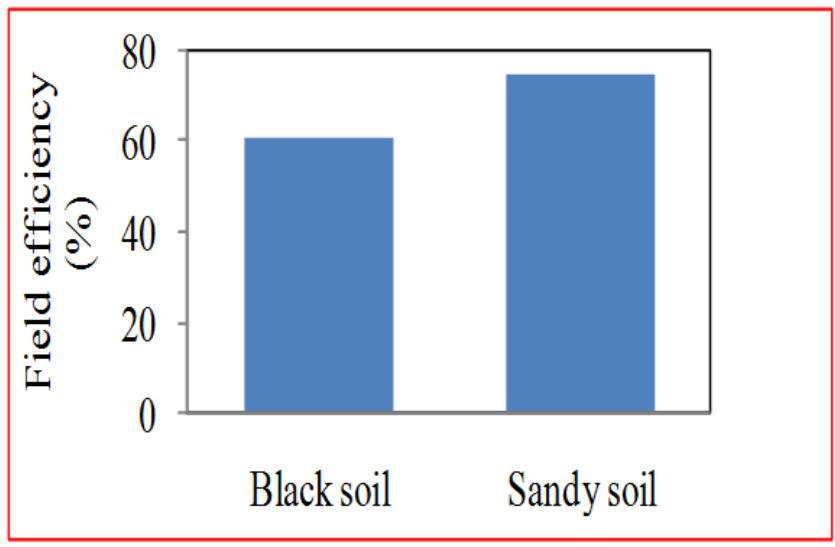


Table.1 Performance of rotary plough in two different soils

\begin{tabular}{|l|l|c|c|}
\hline S.NO & \multicolumn{1}{|c|}{ Parameters } & Black soil & Sandy soil \\
\hline 1. & Width of cut $(\mathrm{cm})$ & 122 & 125 \\
\hline 2. & Depth of cut $(\mathrm{cm})$ & 16 & 19 \\
\hline 3. & Actual field capacity $(\mathrm{ha} / \mathrm{h})$ & 0.18 & 0.28 \\
\hline 4. & Theoretical field capacity $(\mathrm{ha} / \mathrm{h})$ & 0.30 & 0.375 \\
\hline 5. & Field efficiency $(\%)$ & 60.20 & 74.68 \\
\hline 6. & Fuel consumption $(\mathrm{l} / \mathrm{h})$ & 5.14 & 5 \\
\hline 7. & Area of plot covered $\left(\mathrm{m}^{2}\right)$ & $54 \times 35$ & $49 \times 21$ \\
\hline 8. & Time to cover plot $(\mathrm{h})$ & 1.03 & 0.367 \\
\hline 9. & Speed of tractor $(\mathrm{kmph})$ & 2.5 & 3 \\
\hline
\end{tabular}

Performance of rotary plough in two different soils

By working the rotary plough in black and sandy soil the following were observed (Fig. 1).

\section{Fuel consumption}

The average fuel consumption of machine was found to be $5.14 \mathrm{l} / \mathrm{h}$ when used in black soil and 5 l/h when used in sandy soil. The fuel consumption in case of sandy soil may be less due to less stickiness of the soil which posses less load on the engine.

This chapter contains the results and discussions of the experiments conducted in order to fulfill the objective of the study. The available rotary plough in the farmer's field at Ramkur village and Department of farm machinery at College of Agricultural Engineering, Bapatla was tested and its performance was evaluated. The field parameters were carried out in different soils and the comparison was made. The following conclusions were drawn from performance evaluation of the rotary plough. Rotary plough can be used for till great depths, break massive clumps and ensure even leveling in just one pass. It is also very useful for converting a barren land into cultivable. The theoretical field capacity of black and sandy soil as $0.30 \mathrm{ha} / \mathrm{h}$ and $0.37 \mathrm{ha} / \mathrm{h}$. The average effective field capacity of the implement in black and sandy soil was $0.18 \mathrm{ha} / \mathrm{h}$ and 0.27 $\mathrm{ha} / \mathrm{h}$. The field efficiency was 60 and 72 percent in black and sandy soil respectively. The fuel consumption in black and sandy soil was $5.14 \mathrm{l} / \mathrm{h}$ and $5 \mathrm{l} / \mathrm{h}$.

\section{References}

Abdou, F.M.E., 1996. Effect of some seedbed preparation systems and mechanical planting on wheat production. Misr J. Agric. Eng. 13 (1): 44- 58.

Al-Suhaibani, S. A., and A. E. Ghaly, 2010. Performance Evaluation of a Heavy Duty Chisel Plow at Various Tillage Depth and Forward Speeds. American J. of Engineering and Applied Sciences, 3 (4): 588-596.

Głab, T., Kulig, B. 2008. Effect of mulch and tillage system on soil porosity under wheat (Triticum aestivum). Soil Tillage Research, Amsterdam. 99: 169-178.

Hugo González., Nelson L. Cappelli., Alejandro toro. 2013. Wear of rotary plows operating in a tropical clay loam soil. Eng. Agríc, Jaboticabal. 33(4):772-781.

Khadr, K. A. A., 2000. A study some factors affecting the power tiller performance. Misr J. Agric. Eng. 17 (3): 636- 646. 
Sankaran, S., and Mudaliar, V.S. 1984. Principles of Agronomy. Bangalore Print. Publishing Company.

Upadhyaya, S.K., Andrade-Sanchez, P.,
Sakai, K., Chancellor W.J and Godwin, R.J. 2009. Advances in Soil Dynamics. American Society of Agricultural and Biological Engineers. 3: 273-359.

\section{How to cite this article:}

Jithender, B., D.V. Sunitha, K. Upender and Rami Reddy, K.V.S. 2017. Performance Study of Tractor Operated Rotary Plough in Two Different Soils. Int.J.Curr.Microbiol.App.Sci. 6(10): 871-878. doi: https://doi.org/10.20546/ijcmas.2017.610.104 